\title{
Molecular and biological factors in the prognosis
}

\author{
S.D.J.M. Kanters*, J-W.J. Lammers**, E.E. Voest*
}

Molecular and biological factors in the prognosis of non-small cell lung cancer. S.D.J.M. Kanters, J-W.J. Lammers, E.E. Voest. (C)RS Journals Ltd 1995.

ABSTRACT: For patients with non-small cell lung cancer the tumour/node/metastasis (TNM) staging system and other conventional prognostic factors fail to predict the outcome of treatment and survival accurately. New prognostic factors are urgently needed to improve understanding of the biological behaviour of the different subtypes of non-small cell lung cancer and to recognize patients with a good or poor prognosis.

This review will focus on molecular and biological factors published in the English language literature between 1988 and 1994. To be included in this survey, the predictive value of a specific prognostic factor had to be confirmed by multivariate analysis in at least two different studies.

Blood group antigen expression, ras oncogenes, microvessel density, and factors reflecting the proliferative state of the tumour may be important determinants of outcome of treatment. The search for new determinants of prognosis has provided insight in the complex tumour biology of non-small cell lung cancer and indicated possible targets for tumour therapy.

Several promising prognostic factors have now been recognized. To validate these factors, prospective studies of a large patient population are needed. This ultimately serves the recognition of subsets of patients who may benefit from adjuvant therapy. Eur Respir J., 1995, 8, 1389-1397.

\begin{abstract}
*Dept of Internal Medicine, Medical Oncology Unit, and **Dept of Pulmonary Medicine, University Hospital Utrecht, The Netherlands.
\end{abstract}

Correspondence: E.E. Voest

Dept of Internal Medicine

University Hospital Utrecht

P.O. Box 85500

3508 GA Utrecht

The Netherlands.

Keywords: Angiogenesis blood-group antigens

non-small cell lung cancer

oncogenes

prognosis

Received: August 231994

Accepted after revision March 251995
Lung cancer is the leading cause of death from malignancy in the Western world. Non-small cell lung carcinoma accounts for approximately $75 \%$ of the cases and represents a heterogeneous group of cancers consisting mainly of squamous cell, adeno- and large cell carcinoma [1]. During the last decade, the 5 year survival rate of patients with lung cancer has hardly improved. At the time of diagnosis, approximately $80 \%$ of lung cancer patients have unresectable disease. Despite radioand/ or chemotherapy, the 5 year survival of those patients is $2-3 \%$, whereas in the case of a putative complete resection $25-40 \%$ of the patients survive for 5 yrs [1, 2].

The choice of treatment is currently determined by conventional prognostic factors, such as tumour/node/ metastasis (TNM) stage, the extent of lymph node metastases and performance status [3, 4]. However, great differences in outcome after therapy are seen between patients with the same initial stage and performance status. The influence of additional variables may explain this heterogeneous prognosis. Knowledge of these variables may allow us to predict the response to treatment more accurately and select patients who need adjuvant therapy.

In this review, we will give a survey of novel tumour characteristics which may affect the prognosis of patients with non-small cell lung carcinoma. Articles reviewed in this paper were collected using the Medline literature search system. We enclosed both retro- and prospective studies published in the English language literature from 1988 until 1994. Prognostic factors were included when their value was reported in at least two separate studies by independent groups. In addition, multivariate analysis was a prerequisite to show independent prognostic value. Almost all studies reviewed have a sample size of at least 50 patients.

\section{Blood group antigen expression}

Cell surface carbohydrate structures are important for interactions between cells and between the cell and the extracellular matrix. ABH blood group antigens are carbohydrate structures found in erythrocytes and in a variety of epithelial cells. The expression of these antigens depends on the type of blood. In various human cancers, expression of blood group A and B antigens is frequently lost, and there is an increase of their precursor antigen $\mathrm{H}$ and $\mathrm{H}$-related antigens. In normal human cells the expression of $\mathrm{H}$-related structures is higher in $\mathrm{O}$ cells than in A or B cells [5]. In cancerous cells, however, there is enhanced expression of these H-related antigens 
independent of the host's blood group (ABO status). Altered cell surface carbohydrate structures can result in changed cell-cell interactions that give rise to a difference in growth and differentiation, and probably even progression of malignancy [6].

The survival of 164 patients, who underwent complete surgery for non-small cell lung carcinoma, was studied in relation to the expression of $\mathrm{ABH}$ blood-group antigens [7]. Table 1 shows the prognosis of patients with either the presence or the absence of antigen $A$ in their tumour cells. Cox's proportional hazards regression analysis showed that expression of blood group antigen A in tumour cells was an independent prognostic factor for overall survival among patients with blood type $\mathrm{A}$ or $\mathrm{AB}$ $(\mathrm{p}=0.004)$.

$\mathrm{H} / \mathrm{Le} / \mathrm{Le}^{\mathrm{b}}$ blood group antigens are increased in tumours negative for blood group antigens $\mathrm{A}$ and $\mathrm{B}$. This is partially due to inhibition of A and B glycosyltransferases. By aberrant glycosylation, which is common in essentially all forms of cancer, structures like H/Ley/Le ${ }^{b}$ are formed. MIA-15-5, an antibody that recognizes H/Ley/ $\mathrm{Le}^{\mathrm{b}}$, has a strong inhibitory effect on cell motility and the ability to metastasize [9]. A difference in 5 year survival rate was found between the $\mathrm{H} / \mathrm{Le}^{\mathrm{y}} / \mathrm{Le}^{\mathrm{b}}$ antigen-positive group and the antigen-negative group in patients who underwent surgery because of lung carcinoma up to stage IIIA ( $p<0.001$, table 1) [8]. The difference in survival was significant among patients with blood groups $\mathrm{A}$ and $\mathrm{AB}$, but not among those with blood group $\mathrm{B}$ or $\mathrm{O}$. In all three subgroups with squamous cell carcinoma, adenocarcinoma and large cell carcinoma, survival rate was higher in those patients whose tumours stained negatively for MIA-15-5 ( $\mathrm{p}<0.001, \mathrm{p}=0.015$ and $\mathrm{p}=0.02$, respectively). For the study population overall, in multivariate analysis $\mathrm{H} / \mathrm{Le}^{\mathrm{y}} / \mathrm{Le}^{\mathrm{b}}$ positivity was the most important prognostic factor, followed by $\mathrm{N}$ and $\mathrm{T}$ stage.

\section{Oncogenes and tumour suppressor genes}

Proto-oncogenes may induce autonomous cellular proliferation when activated to oncogenes. Activation may occur by point mutation, overexpression or deletion of genetic material. Proto-oncogenes are usually dominant. Best known oncogenes in lung cancer are the ras and $m y c$ oncogenes, of which the latter has been found mainly in small cell lung carcinoma [10]. On the other hand,

Table 1. - Effect of blood group antigen expression on prognosis of non-small cell lung cancer patients

\begin{tabular}{|c|c|c|c|}
\hline $\begin{array}{l}\text { Author } \\
\text { [Ref.] }\end{array}$ & $\begin{array}{l}\text { Blood group } \\
\text { antigen }\end{array}$ & $\begin{array}{l}\text { Pts } \\
\mathrm{n}\end{array}$ & $\begin{array}{c}5 \text { year } \\
\text { survival } \\
\%\end{array}$ \\
\hline $\begin{array}{l}\text { LEE } e t a l \text {. } \\
\text { [7] }\end{array}$ & $\begin{array}{l}\text { Blood } \mathrm{A} \text { or } \mathrm{B} \text {, tumour } \mathrm{A}^{-} \\
\text {Blood } \mathrm{A} \text { or } \mathrm{AB} \text {, tumour } \mathrm{A}^{+} \\
\text {Blood } \mathrm{B} \text { or } \mathrm{O}\end{array}$ & $\begin{array}{l}28 \\
43 \\
93\end{array}$ & $\begin{array}{l}15 \\
59 \\
38\end{array}$ \\
\hline $\begin{array}{l}\text { MiKAYE et al. } \\
{[8]}\end{array}$ & $\begin{array}{l}\mathrm{H} / \mathrm{Le}^{\mathrm{y}} / \mathrm{Le}^{\mathrm{b}} \text { positive } \\
\mathrm{H} / \mathrm{Le}^{\mathrm{y}} / \mathrm{Le}^{\mathrm{b}} \text { negative }\end{array}$ & $\begin{array}{l}91 \\
58\end{array}$ & $\begin{array}{l}21 \\
59\end{array}$ \\
\hline
\end{tabular}

Pts: patients; [Ref.]: reference number. inactivation of genes that normally regulate cellular growth and thereby have a restraining effect on tumorgenesis (tumour suppressor genes) can lead to uncontrolled cell proliferation. In many cases, inactivation occurs by a point mutation of one allele and, subsequently, loss of an amount of genetic material in the other allele. For many types of cancer, multiple mutations in both classes of genes are ultimately required to achieve full malignant transformation.

\section{Ras oncogenes}

The ras proto-oncogene family includes the genes $\mathrm{K}$-, $\mathrm{H}$-and $\mathrm{N}$-ras, which encode $21 \mathrm{kDa}$ (p21) guanosine triphosphate-binding proteins. These proteins are associated with the inner cell membrane and have an important role in the cellular signal transduction [11-13]. Point mutations at codon 12,13 or 61 change ras genes to oncogenic forms. This results in continuous stimulation of cellular growth. The activated ras genes are among the most dominant identified oncogenes in human tumours [14]. The reported incidence of ras mutations in non-small cell lung cancer varies. In 77 samples from operated patients with non-small cell lung carcinoma, a total of $14 \mathrm{~K}$-ras mutations were detected (all in the 12th codon) and only one H-ras mutation (table 2) [15, 16]. All of these were encountered in the 45 adenocarcinomas. It was suggested that K-ras activation is present in about one third of all adenocarcinomas of the lung at thoracotomy, but only rarely in other types of non-small cell lung cancer. The median follow-up of 10 months was insufficient to evaluate survival data.

Other investigators also found K-ras mutations in squamous cell carcinoma, adenocarcinoma and in patients with large cell undifferentiated carcinoma [17]. Patients with $\mathrm{K}$-ras point mutations had significantly poorer prognosis than patients without the mutation $(\mathrm{p}=0.01)$. This difference was also significant when stratified according to node status. In another study, the prognostic value of K-ras oncogene activation in adenocarcinoma was investigated in a group of 69 patients in whom complete resection of the tumour was possible [18]. Nineteen tumours harboured a point mutation in codon 12 of the $\mathrm{K}-\mathrm{ras}$ oncogene. These tumours tended to be less differentiated and smaller at the time of diagnosis than the tumours without this mutation. A difference in prognosis was found in all three end-points considered: duration of disease free survival $(\mathrm{p}=0.038)$, overall survival $(\mathrm{p}=0.002)$; and number of deaths due to cancer $(\mathrm{p}<0.001)$.

Table 2. - Effect of ras oncogene activation on prognosis of non-small cell lung cancer patients

\begin{tabular}{|c|c|c|c|}
\hline Author [Ref.] & $\begin{array}{c}\text { Pts } \\
\mathrm{n}\end{array}$ & $\begin{array}{c}\text { K-ras } \\
\text { mutations } \\
\%\end{array}$ & $\begin{array}{c}\text { Survival } \\
\text { difference } \\
\text { p-value }\end{array}$ \\
\hline Rossell et al. [17] & 66 & 20 & 0.01 \\
\hline SLebos et al. [18] & 69 & 29 & 0.002 \\
\hline Sugio et al. [19] & 115 & 16 & 0.02 \\
\hline
\end{tabular}

Pts: patients; [Ref.]: reference number. 
Eighteen of 115 Japanese patients with surgically resected adenocarcinomas of the lung carried a point mutation in the ras gene [19]. There were no significant differences related to stage of disease or TNM classification between ras mutated and non-mutated tumours. For patients without lymph node metastasis, 5 year survival rate in the ras-positive group was significantly poorer than in the ras-negative group $(\mathrm{p}=0.02)$. This difference in survival could not be established in the advanced stages of cancer.

Enhanced expression of the protein $\mathrm{p} 21$, which is encoded by the ras proto-oncogene, can be detected by antiras monoclonal antibodies. In 116 surgically treated patients with non-small cell lung cancer, positive reactions were observed in $73 \%$ of the adenocarcinomas, $71 \%$ of the large cell carcinomas, and $56 \%$ of the squamous cell carcinomas studied [20]. Five year survival rate was significantly higher for patients with p21-negative tumours than for patients with $\mathrm{p} 21$-positive tumours $(\mathrm{p}<0.05)$. On Cox's multivariate analysis, p21 staining was found to be an even more important prognostic factor than stage of disease.

\section{Her2/neu oncogene}

The Her2/neu gene (also called c-erbB-2 gene) encodes for the transmembrane protein $\mathrm{p} 185^{\text {neu }}$, which shows extensive homology to the receptor for epidermal growth factor. Expression of the Her2/neu gene product occurs in approximately one third of the non-small cell lung cancers [21].

KERN et al. [22] reported that 10 of 29 adenocarcinomas and 5 of 16 squamous cell carcinomas overexpressed $\mathrm{p} 185^{\text {neu }}$ in comparison with levels of expression seen in uninvolved bronchiolar epithelium. None of 10 large cell carcinomas reacted with DBW-2 antiserum. On multivariate analysis, expression of $\mathrm{p} 185^{\text {neu }}$ was found to be a prognostic factor in patients with adenocarcinoma $(p=0.04)$. Overall survival was about 84 weeks for patients with adenocarcinoma expressing $\mathrm{p} 185^{\mathrm{neu}}$, compared to 189 weeks for those without expression of this oncogene $(\mathrm{p}=0.01)$. For squamous cell carcinomas, this relationship could not be established. In a later study of 44 patients with adenocarcinomas of all stages, 26 patients of the former research were included [23]. Her2/neu was expressed in $34 \%$ of the tumours. Multivariate analysis by the Cox's proportional hazards model identified Her2/neu expression as an independent unfavourable prognostic factor $(\mathrm{p}=0.01)$.

\section{Bcl-2 oncogene}

The $b c l-2$ oncogene encodes a protein that inhibits programmed cell death (apoptosis) [24]. It is thought that the expansion of cell populations overexpressing $b c l-2$ is a result of the lack of programmed cell death. This expansion occurs at a rate slower than that of growth induced by oncogenes directly affecting cell proliferation [25]. $B c l-2$ protein was found in 20 of 80 surgically resected squamous cell carcinomas, and in 5 of 42 resected adenocarcinomas [26]. In adjacent areas of normal epithelium, basal cells showed positive staining for $b c l-2$, but the more differentiated columnar cells remained negative. In the group of patients with squamous cell carcinoma, 5 year survival was higher for patients with $b c l-2$ positive tumours $(78 \%$ compared to $48 \%, \mathrm{p}<0.05)$. On Cox's regression analysis of the whole population, $b c l-2$ expression was not a significant prognostic factor. Analysis of the squamous cell carcinoma group showed that it was an even better predictor of survival than $\mathrm{N}$ stage. An explanation for the less aggressive behaviour of $b c l-2$ positive tumour cells has not yet been found. It has been suggested that in clones in which a low mitotic rate is offset by $b c l-2$ expression, the rate of acquiring complementary defects is slower than in clones with a high mitotic rate [27].

\section{p53 suppressor gene}

The p53 gene is thought to regulate transcription of deoxyribonucleic acid (DNA) [28]. The wild-type p53 protein blocks the progression of cells through the cell cycle late in the G1 phase of replication. The mutant protein does not have this function and may even promote cellular proliferation. Alterations in this gene are the most common genetic changes associated with cancer $[29,30]$. They may be present in germ cells or somatic cells. The predisposition to cancer in persons harbouring such germline mutations appears to be inherited as a dominant trait. The inherited forms of p53 mutations were first described in families with the LiFraumeni cancer syndrome, that is characterized by multiple tumours of early onset $[31,32]$. The wild-type p53 gene product is found in the nucleus as a low abundance protein, whereas many mutant forms have much longer half-lives and accumulate in the nucleus. A mutation rate of nearly $50 \%$ has been described in non-small cell lung cancer [33-38].

The $50 \%$ survival time of 114 patients with stage I or II adenocarcinomas or squamous cell carcinomas was reported to be 16 months for p53 producers, compared with 38 months for nonproducers $(p<0.001)$ [35]. The correlation between p53 production and survival applied to both stage I and stage II carcinomas, when they were analysed separately. Furthermore, 7 of the 24 stage II non-small cell lung cancers that were p53negative, had regional lymph node metastatic sites that were p53-positive. These specific patients had a mean survival time that was only one third than that of stage II patients who remained p53-negative at nodal metastatic sites (11 months and 34 months, respectively; $\mathrm{p}<0.009)$.

In another study, p53 overexpression was observed in 25 of 71 primary and 23 of 52 metastatic non-small cell lung tumours [37]. It was found in 35 of 75 adenocarcinomas, 8 of 23 large cell carcinomas, 2 of 13 squamous cell carcinomas, and 4 of 12 carcinomas of other histological subtypes. In multivariate analysis, overexpression of $\mathrm{p} 53$ proved to be an independent prognostic factor in the curative intent group $(\mathrm{p}=0.001)$.

In 71 patients with non-small cell lung carcinoma, who underwent complete resection by radical surgery, 
the presence of p53 mutation was associated with a shortened survival ( $\mathrm{p}=0.014, \log$ rank test) [34]. Multivariate analysis also revealed that p53 was an unfavourable prognostic factor with a risk ratio of $3.5(\mathrm{p}=0.013)$.

Other investigators could not establish a relationship between p53 immunostaining and survival. Of 125 radically resected primary lung tumours, $54 \%$ stained positively for p53: 59\% of 78 squamous cell carcinomas, $52 \%$ of 42 adenocarcinomas; and $20 \%$ of five small cell carcinomas [38]. Survival analyses of all cases and squamous and adenocarcinomas seperately showed no statistical difference between negative and positive cases.

\section{$3 p$ deletion}

Deletion of a part of the short arm of chromosome 3 (3p) is frequent (50\% or more) in non-small cell lung cancer and is found in $100 \%$ of small cell lung cancers. This strongly suggests the presence of a tumour suppressor gene(s) in this 3p chromosomal region [39, 40]. The precise location of this putative tumour suppressor gene(s) and the effect of deletion on survival are still unknown.

HORIO and co-workers [34] detected 3p deletions in 34 of 70 resected non-small cell lung cancers. Patients with the $3 p$ deletion tended to have a poorer prognosis $(p=0.084$, all patients; $\mathrm{p}=0.068$, patients with stage I or II disease, $\log$ rank test).

\section{Vasculature}

\section{Angiogenesis}

The induction of angiogenesis is now a well-established step in carcinogenesis [41]. Most preneoplastic lesions lack obvious neovascularization, whilst the resulting tumours are highly angiogenic. Tumour growth and metastasis can be divided in two stages. At first, there is a prevascular phase with local invasion of the primary tumour. This phase is usually long-lasting and associated with limited tumour growth. Next there is a vascular phase with blood and lymphatic vessel invasion. This phase is short-lasting and associated with rapid tumour growth. Dissemination of tumour cells occurs more often at this stage [42]. Ingrowth of new capillaries seems to occur under the influence of angiogenic factors [43]. New proliferating capillaries have fragmented basement membranes and their leakiness may facilitate penetration by tumour cells [44]. The ingrowth of new capillaries increases the opportunity for tumour cells to enter the circulation [45]. Microvessel density of tumours can be determined by staining for factor VIIIrelated antigen.

In 87 T1N0M0 non-small cell lung cancer patients who were treated with complete surgery, microvessel density was compared with other well-known prognostic factors [46]. Twenty two patients developed postoperative metastasis. These patients had significantly higher mean microvessel density counts than the patients without metastasis $(\mathrm{p}<0.0001)$. Other prognostic factors were tumour size and proliferative activity. However, on multivariate analysis, the microvessel density count was found to be the only independent predictor of metastasis $(\mathrm{p}<0.0001)$.

Tumour specimens from 28 patients, with resected nonsmall cell lung cancer involving the thoracic inlet, were analysed for the presence and degree of angiogenesis [47]. Seventy one percent of the tumours exhibited areas of angiogenesis. The median density grade was 1 , and the median number of neovessels was 6 . On multivariate analysis, angiogenesis was the only independent and significant predictor of survival. Patients whose tumours had a density grade of 1 or more and a number of neovessels of 6 or more (high risk), had a significantly worse disease-free interval $(\mathrm{p}=0.0001)$, and higher relative risk of suffering systemic recurrence of their primary tumour $(p=0.0001)$, than did their low-risk counterparts.

These findings suggest that the degree of vascular neoformation is associated with the prognosis of patients with non-small cell lung carcinoma.

\section{Tumour invasion in vessels}

Besides inducing angiogenesis, tumour cells are also capable of penetrating pre-existent vessels, thereby entering the circulation. This may clearly facilitate the development of metastasis. Arterial or venous vascular invasion by tumour cells was present in $77 \%$ of 87 patients who underwent lobectomy or pneumectomy for adenocarcinoma or squamous cell carcinoma [48]. Neither the presence, nor the absence, nor the proportion of vasoinvasion was related to survival.

Tumour invasion in vessels was also analysed in 45 patients with peripheral, superficially seated, nodenegative non-small cell lung carcinoma, treated with wedge resection alone [49]. In $15 \%$ of the resected neoplasms, tumour cells were seen within a blood channel. Patients with tumour invasion in vessels had a significantly higher recurrence of disease and death from nonsmall cell lung cancer $(\mathrm{p}=0.0009)$. On multivariate analysis, only the presence or absence of blood vessel invasion retained an independent level of significance $(\mathrm{p}=0.006)$.

\section{Nucleolar organizer regions}

The nucleolus contains large loops of DNA emanating from several chromosomes. Each of these loops contains a cluster of ribosomal ribonucleic acid (rRNA) genes, known as a nucleolar organizer region (NOR) [50]. The rRNA genes are transcribed by RNA polymerase I, after which they are packaged with ribosomal proteins to form ribosomes. Nucleolar organizer regions can be visualized by silver staining of their associated proteins (Ag-NORs) on paraffin-embedded blocks [51]. The number of Ag-NORs per nucleus correlates with cellular differentiation and activity and may, therefore. be a prognostic factor in malignant tumours.

In 274 patients with non-small cell lung cancer, the mean number of Ag-NORs per nucleus of stage T1 or T2 disease was statistically lower than that in cases of 
T3 or T4 disease $(\mathrm{p}<0.01)$. The mean number of AgNORs in N0 disease was statistically lower than in N1 or $\mathrm{N} 2$ disease $(\mathrm{p}<0.01)$. A similar pattern was seen in patients with stage I when compared with stages II, IIIA, IIIB or IV $(p<0.01)$ [52]. According to the histological type, the mean number of Ag-NORs per nucleus of adenocarcinoma was statistically lower than that in cases of squamous cell carcinoma $(\mathrm{p}<0.01)$ or large cell carcinoma $(\mathrm{p}<0.05)$. IsHIDA et al. [53] found the same concerning stage and histological type.

Five year overall survival rates of patients with low (less than the mean number) and high (a mean number or more) Ag-NOR counts were 56 and $25 \%$, respectively $(\mathrm{p}<0.001)$ [52]. In 131 patients with stage I disease and adenocarcinoma, 5 year survival was $78 \%$ in patients with low Ag-NOR counts, which was significantly higher than the $25 \% 5$ year survival in patients with high Ag-NOR counts. This difference in survival could not be established for the other stages and histological subtypes other than adenocarcinoma.

\section{Tumour proliferation and DNA content}

Markers of cellular proliferation have been studied extensively. They are summarized in table 3 . In a variety of cancers, tumours with abnormal DNA content (aneuploidy) or a high proliferative fraction appear to have a more aggressive biological behaviour and worse prognosis $[67,68]$. Several studies have reported DNA content to be a significant prognostic variable in a variety of non-small cell types and stages [54-56]. Others did not find this association [57-59]. Some investigators found tumour ploidy to be valuable only for squamous cell carcinoma [60, 61].

The proliferative potential of tumours depends on the growth fraction and the transit time through the various phases of the cell cycle. Ki-67 is a nonhistone protein of the nuclear matrix that is preferentially expressed during the late $G_{1}, S, G_{2}$ and $M$ phases of the cell cycle [69]. Immunostaining for this protein provides a reliable method for evaluation of the tumour growth fraction [70]. Immunostaining for the antigen $\mathrm{Ki}-67$ was used to derive the tumour proliferation index for 62 surgically resected non-small cell lung tumours [62]. A significant survival advantage was observed for patients with a proliferation index of less than 3.5, compared with those with an index greater than $3.5(\mathrm{p}=0.01)$. At 24 months, both groups of patients had an estimated probability of survival of 0.54 and 0.08 , respectively.

The percentage of tumour cells with an S phase DNA content is another measure of proliferative activity. In 44 stage I patients, 5 year survival was $93 \%$ for patients with less than $8 \% \mathrm{~S}$ phase cells, and $21 \%$ for those with a greater percentage of $S$ phase cells $(p<0.001)$ [56]. S phase fraction was also calculated in a group of 49 patients with non-small cell lung cancer of all stages [59]. Patients were divided into two categories: $\mathrm{S}$ phase fraction $\leq 17 \%$; and $S$ phase fraction $>17 \%$. The $S$ phase fraction was not related to histology or stage of disease, but a significant prognostic value was found for survival; patients with a high $\mathrm{S}$ phase fraction died earlier $(\mathrm{p}=0.04)$.
Table 3. - Effect of tumour proliferation and DNA content on prognosis of non-small cell lung cancer patients

\begin{tabular}{lrcc}
\hline Factor & $\begin{array}{c}\text { Pts } \\
\mathrm{n}\end{array}$ & $\begin{array}{c}\text { Predictive } \\
\text { of survival }\end{array}$ & {$[$ Ref.] } \\
\hline DNA content & 100 & Yes & {$[54]$} \\
& 64 & Yes & {$[55]$} \\
& 44 & Yes & {$[56]$} \\
& 93 & No & {$[57]$} \\
& 52 & No & {$[58]$} \\
& 67 & No & {$[59]$} \\
Ki-67 & 130 & only for SCC & {$[60]$} \\
S phase fraction & 146 & only for SCC & {$[61]$} \\
& 62 & Yes & {$[62]$} \\
Thymidine labelling & 44 & Yes & {$[56]$} \\
Index & 49 & Yes & {$[59]$} \\
Polymerase $\alpha$ & 49 & & \\
PCNA & 43 & Yes & {$[63]$} \\
& 40 & Yes & {$[64]$} \\
& 211 & Yes & {$[65]$} \\
& & Yes & {$[66]$} \\
\hline
\end{tabular}

SCC: squamous cell carcinoma; DNA: deoxyribonucleic acid; PCNA: proliferating cell nuclear antigen; Pts: patients; [Ref.]: reference number.

The thymidine labelling index reflects the percentage of tumour cells which are actually in the $\mathrm{S}$ phase and do synthesize DNA. On multivariate analysis of 89 nonsmall cell lung cancer patients who underwent complete surgery, a twofold increase in the risk of death was reported in the group of patients with a thymidine labelling index greater than the overall median thymidine labelling index of $2.9(\mathrm{p}=0.057)$ [63].

DNA polymerase $\alpha$ plays a crucial role in the replication of DNA and is active in the nucleus in the G1/S or G2 phase [71]. Polymerase $\alpha$ levels were examined in 43 non-small cell lung cancer patients with complete resection [64]. The overall 3 year disease-free survival rate was $42 \%$ for patients who were polymerase $\alpha$-positive, which was significantly lower than the $81 \%$ survival for those who were polymerase $\alpha$-negative $(\mathrm{p}<0.05)$.

Proliferating cell nuclear antigen (PCNA) is a $36 \mathrm{kDa}$ nuclear protein binding to DNA polymerase $\delta$, and is associated with DNA replication [72]. In 40 peripheral, nodenegative non-small cell lung cancer patients treated with surgery alone, PCNA was found in all tumour samples [65]. It was confined to the nuclei of cancer cells. On multivariate analysis, the degree of PCNA was the only independent prognostic factor of survival. In 211 surgically resected primary non-small cell lung carcinomas the prognostic value of PCNA expression and nucleolar organizer regions was evaluated [66]. Of the $211 \mathrm{spec}-$ imens examined, there were $69(33 \%)$ with PCNA(+) and $92(44 \%)$ with a high Ag-NOR count (a mean number or more). The 5 year survival rates of patients with PCNA(+) and high Ag-NOR counts, those with PCNA$(+)$ or high Ag-NOR counts and those with PCNA(-) and low Ag-NOR counts were 18, 37 and $71 \%$, respectively $(\mathrm{p}<0.05)$. On Cox's multivariate regression analysis, 
PCNA and Ag-NOR were selected as independent prognostic factors $(\mathrm{p}<0.005)$.

\section{Nuclear morphometry}

Morphometric analysis of nuclear shape and size proved to be useful in predicting prognosis in certain forms of cancer [73-77]. Nuclear properties can be measured with a computer-assisted digitizing system. In 75 patients who underwent surgical resection of an adenocarcinoma of the lung smaller than $2 \mathrm{~cm}$, the mean nuclear area and the standard deviation of nuclear area were determined [78]. The mean nuclear area of the cancer cells was unrelated to prognosis. The 5 year survival rates of patients with small, medium and large standard deviation of nuclear area, were 75,58 and $52 \%$, respectively $(\mathrm{p}<0.05)$. On multivariate analysis, standard deviation of nuclear area was a marginally significant prognostic factor $(\mathrm{p}=0.05)$. In patients with stage I non-small cell lung cancer, there was no correlation between morphometric parameters (nuclear area, perimeter, major diameter, minor diameter and nuclear shape factor) and disease free survival [79].

\section{Neural cell adhesion molecule}

The neural cell adhesion molecules are a family of cell surface sialoglycoproteins involved in homotypic and heterotypic cell-cell binding via a homophilic mechanism. Abnormal patterns or levels of expression of adhesion molecules on the cell membrane, which cause changes in normal cellular adhesiveness, may play an important role in tumour invasion and metastasis. The monoclonal antibody (MoAb) 123C3 recognizes the neural cell adhesion molecule in frozen sections [80]. The neural cell adhesion molecule has a wider tissue distribution than just the neural and neuroendocrine cells. It was found to be positive in all neuroendocrine lung tumours and in $20 \%$ of non-small cell lung carcinomas tested [81]. The expression of the neural cell adhesion molecule in 226 completely resected non-small cell lung cancer patients was investigated [82]. A significantly shorter disease-free and overall survival was seen for subjects with tumours positive for MoAb 123C3, also when corrected for differences in tumour stage (disease-free survival $\mathrm{p}=0.044$, overall survival $\mathrm{p}=0.046$ ).

In another study, neural cell adhesion molecule expression was determined in the tumours of 97 surgically treated lung cancer patients, using the MoAbs MOC-1 and S-L 11.14 [83]. Neural cell adhesion molecule expression was found in all nine small cell lung cancers and in $18 \%$ of the non-small cell lung cancers. Neural cell adhesion molecule expression was significantly higher in stage N2 non-small cell lung carcinomas, compared with stage N0 or N1 disease. In univariate analysis, patients with neural cell adhesion molecule-positive nonsmall cell lung cancer proved to have a shorter survival than those with neural cell adhesion molecule-negative disease. On Cox's multivariate analysis, it's prognostic value could not be established.

\section{Discussion}

The currently used prognostic factors, such as stage of disease, performance status, and histology, fail to provide an accurate prediction of the course of the disease in patients with non-small cell lung cancer. The discovery of new prognostic factors is extremely important, since it allows discrimination between patients in highor low-risk groups with respect to recurrence of the disease and long-term survival. A large number of new molecular and biological factors have been reported and are now recognized as independent predictors of outcome of treatment. In table 4 all prognostic factors are summarized. In this table, we try to indicate the prognostic value of each factor separately. In most studies, the group of large cell carcinoma patients is too small to find a statistically significant difference in outcome. We, therefore, summarize the prognostic value of the variables in adenocarcinoma and squamous cell carcinoma.

When one evaluates a prognostic factor for its clinical merit there are several considerations to be made. Firstly, is the method of detection simple and can it be standardized? This is important, since new prognostic factors are often demonstrated with the use of molecular biological methods. For instance, ras gene mutations are usually established by oligonucleotide hybridization.

Table 4. - Prognostic value concerning survival of molecular and biological factors in adenocarcinoma (AC) and squamous cell carcinoma (SCC) of the lung

\begin{tabular}{lccc}
\hline & AC & SCC & {$[$ Ref.] } \\
\hline $\begin{array}{l}\text { Blood group antigen } \\
\text { expression }\end{array}$ & + & ++ & {$[7,8]$} \\
Oncogenes & & & \\
Ras oncogenes & ++ & + & {$[17-20]$} \\
Her2/neu oncogene & + & - & {$[22,23]$} \\
Bcl-2 oncogene & - & + & {$[26]$} \\
Tumour suppressor genes & & & \\
p53 suppressor gene & \pm & \pm & {$[34,35,37,38]$} \\
3p deletion & \pm & \pm & {$[34]$} \\
Vasculature & & & \\
Angiogenesis & + & + & {$[46.47]$} \\
Tumour invasion in vessels & \pm & \pm & {$[48,49]$} \\
Nucleolar organizer regions & + & - & {$[52]$} \\
Tumour ploidy & \pm & \pm & {$[54-61]$} \\
Tumour proliferation & & & \\
Ki-67 & \pm & \pm & {$[62]$} \\
S phase fraction & + & + & {$[56,59]$} \\
Thymidine labelling index & \pm & \pm & {$[63]$} \\
Polymerase $\alpha$ & \pm & \pm & {$[64]$} \\
PCNA & + & + & {$[65.66]$} \\
Nuclear morphometry & \pm & - & {$[78,79]$} \\
Neural cell adhesion & \pm & \pm & {$[82,83]$} \\
molecule & & & \\
AC: and & & &
\end{tabular}

AC: adenocarcinoma. For further abbreviations see legend to table 3. ++: proven independent prognostic significance; +: probable independent prognostic significance; \pm : inconclusive prognostic value based on either contradictory or unconfirmed studies; -: no prognostic influence has been established. 
The polymerase chain reaction makes this a very sensitive method to identify the mutated codon [84]. In addition, is it possible to employ the method on paraffinembedded specimen or does it require fresh tissue samples? Fortunately, most prognostic factors (e.g. blood group antigens, ras gene mutations and angiogenesis) can be detected on paraffin sections.

Secondly, is the prognostic factor specific for tumour cells or does it merely represent an enhanced expression of a naturally ocurring product. Clearly, the former will have a greater impact than the latter.

Thirdly, is the prognostic factor a truly independent predictor of outcome? Most reported factors are recognized in retrospect and the cut-off point for tumours that were positive or negative for a specific marker was in most cases not predetermined. To be able to weigh the importance of prognostic factors, prospective studies are needed with sufficient numbers of patients to compare a panel of determinants of outcome of treatment in a statistically sound way. In this way, independent factors can be selected and used in the design of new treatment strategies.

In addition to having a prognostic value, the search for molecular and biological factors has also provided new opportunities to treat patients with non-small lung cancer. For instance, three strategies to inhibit the ras oncogene have been described. Inhibition of ras gene mutation expression suppresses tumour growth [85]. Ras function can be suppressed by inhibition of contact between ras protein and downstream effector molecules (kinases). Furthermore, the association of ras protein with the plasma membrane is a process which is catalysed by farnesyl transferase. Specific inhibitors of this enzyme may reduce ras activity [86, 87]. The third strategy involves the use of cytotoxic T-lymphocytes specific for the mutant epitope [88]. Other examples are MoAbs against $\mathrm{H} / \mathrm{Le}^{\mathrm{y}} / \mathrm{Le}^{\mathrm{b}}$ antigens, which have inhibitory effects on cell motility and metastasis [9]. Evaluation of microvessel density provides information on oxygen and drug accessibility of the tumour, which may correlate with the efficacy of radio- or chemotherapy. Finally, tumours with neuroendocrine marker expression are highly sensitive in vitro to treatment with cytotoxic drugs [89].

In conclusion, the lack of improvement in survival of patients with non-small cell lung carcinoma urges the design of new treatment modalities and the selection of subgroups of patients who may benefit the most. For this reason, it is important to recognize specific tumour cell characteristics which may not only serve as a prognostic factor but also as a possible target for tumour therapy. Unfortunately, most studies evaluating tumour markers are performed retrospectively and on a relatively small number of patients. Therefore, at this time point, no definite conclusions on the value of most prognostic factors can be drawn. We have illustrated that blood group antigen expression, ras oncogenes, angiogenesis, and other putative prognostic variables may have prognostic and therapeutic value. Prospective studies are, therefore, highly needed. These studies should include a sufficiently large patient population for statistically sound comparison of promising novel molecular markers.
Ultimately, this may improve the survival of patients with non-small cell lung cancer.

Acknowledgements: The authors thank S. Rodenhuis and G.H. Blijham for their critical review of the manuscript.

\section{References}

1. Capewell S, Sudlow M. Performance and prognosis in patients with lung cancer. Thorax 1990; 45: 951-956.

2. Naruke T, Goya T, Tsuchiya R, Suemasu K. Prognosis and survival in resected lung carcinoma based on the new international staging system. J Thorac Cardiovasc Surg 1988; 96: 440-447.

3. Mountain C. A new international staging system for lung cancer. Chest 1986; 89: 225S-233S.

4. Shields T. The significance of ipsilateral mediastinal lymph node metastasis (N2 disease) in non-small cell carcinoma of the lung: a commentary. Ann Thorac Surg 1990; 48: 48-53.

5. Hakomori S, Kobata A. Blood group antigens. In: Sela M, ed. The antigens. Vol. 2. New York, Academic Press, 1974; pp. 79-140.

6. Hakomori S. Aberrant glycosylation in tumours and tumor-associated carbohydrate antigens. Adv Cancer Res 1989; 52: 257-331.

7. Lee J, Ro J, Sahin A, et al. Expression of blood-group antigen A: a favorable prognostic factor in non-small cell lung cancer. N Engl J Med 1991; 324: 1084-1090.

8. Mikaye M, Taki T, Hitomi S, Hakomori S. Correlation of expression of $\mathrm{H} / \mathrm{Le}^{\mathrm{y}} / \mathrm{Le}^{\mathrm{b}}$ antigens with survival in patients with carcinoma of the lung. N Engl J Med 1992; 327: $14-18$.

9. Miyake M, Hakomori S. A specific cell surface glycoconjugate controlling cell motility: evidence by functional monoclonal antibodies that inhibit cell motility and tumor cell metastasis. Biochemistry 1991; 30: 3328-3334.

10. Little C, Nau M, Carney D, Gazdar A, Minna J. Amplification and expression of the c-myc oncogene in human lung cancer cell lines. Nature 1983; 306: 194-196.

11. Barbacid M. Ras oncogenes. Annu Rev Biochem 1987; 56: 779-827.

12. Hall A. The cellular functions of small GTP-binding proteins. Science 1993; 260: 635-640.

13. Bollag G, McCormick F. Regulators and effectors of ras proteins. Аnпu Rev Cell Biol 1993; 7: 601-632.

14. Bos J. The ras gene family and human carcinogenesis. Mutat Res 1988; 195: 255-271.

15. Rodenhuis S, Slebos R, Boot A, et al. Incidence and possible clinical significance of K-ras oncogene activation in adenocarcinoma of the human lung. Cancer Res 1988; 48: 5738-5741.

16. Rodenhuis S, Van De Wetering M, Mooi W, Evers S, Van Zandwijk N, Bos J. Mutational activation of the $\mathrm{K}$-ras oncogene: a possible pathogenetic factor in adenocarcinoma of the lung. $N$ Engl J Med 1987; 317: 929-935.

17. Rosell R, Li S, Skacel Z, et al. Prognostic impact of mutated K-ras gene in surgically resected non-small cell lung cancer patients. Oncogene 1993; 8: 2407-2412.

18. Slebos R, Kibbelaar R, Dalesio O, et al. K-ras oncogene activation as a prognostic marker in adenocarcinoma of the lung. $N$ Engl J Med 1990; 323: 561-565.

19. Sugio K, Ishida T, Yokoyama H, Inoue T, Sugimachi K, Sasazuki T. Ras gene mutations as a prognostic marker in adenocarcinoma of the human lung without lymph node metastasis. Cancer Res 1992; 52: 2903-2906. 
20. Harada M, Dosaka-Akita H, Miyamoto H, Kuzumaki N, Kawakami Y. Prognostic significance of the expression of ras oncogene product in non-small cell lung cancer. Cancer 1992; 69: 72-77.

21. Weiner D, Nordberg J, Nowell P, et al. Expression of the neu gene encoded protein (p185 $\left.{ }^{\text {neu}}\right)$ in human nonsmall cell carcinomas of the lung. Cancer Res 1990; 50: 421-425.

22. Kern J, Schwartz D, Nordberg J, et al. P185 neu expression in human lung adenocarcinomas predicts shortened survival. Cancer Res 1990; 50: 5184-5191.

23. Kern J, Slebos R, Top B. C-erbB-2 expression and codon $12 \mathrm{~K}$-ras mutations both predict shortened survival for patients with pulmonary adenocarcinomas. J Clin Invest 1994; 93: 516-520.

24. Hockenbery D, Nuñez G, Milliman C, Schreiber R, Korsmeyer S. Bcl-2 is an inner mitochondrial membrane protein that blocks programmed cell death. Nature 1990; 348: 334-336.

25. Hockenbery D, Zutter M, Hickey W, Nahm M, Korsmeyer S. $B c l-2$ protein is topographically restricted in tissues characterized by apoptotic cell death. Proc Natl Acad Sci USA 1991; 88: 6961-6965.

26. Pezzella F, Turley H, Kuzu I, et al. Bcl-2 protein in non-small cell lung carcinoma. N Engl J Med 1993; 329: 690-694.

27. McDonnell T, Deane N, Platt F, et al. Bcl-2-immunoglobulin transgenic mice demonstrate extended B-cell survival and follicular lymphoproliferation. Cell 1989; 57: 79-88.

28. Levine A. The p53 tumor-supressor gene. N Engl J Med 1992; 326: 1350-1352.

29. Nigro J, Baker S, Presinger A, et al. Mutations in the p53 gene occur in diverse human tumor types. Nature 1989; 342: 705-708.

30. Hollstein M, Sidransky D, Vogelstein B, Harris C. P53 mutations in human cancers. Science 1991; 253: 4953.

31. Malkin D, Li F, Strong L, et al. Germline p53 mutations in a familial syndrome of breast cancer, sarcomas, and other neoplasms. Science 1990; 250: 1233-1238.

32. Srivastava S, Zou Z, Pirollo K, Blattner W, Chang E. Germ-line transmission of a mutated p53 gene in a cancer-prone family with Li-Fraumeni syndrome. Nature 1990; 348: 747-749.

33. Suzuki H, Takahashi T, Kuroishi T, Suyama M, Anyoshi Y, Takahashi T. P53 mutations in non-small cell lung cancer in Japan: association between mutations and smoking. Cancer Res 1992; 52: 734-736.

34. Horio Y, Takahashi T, Kuroishi T, et al. Prognostic significance of $\mathrm{p} 53$ mutations and $3 p$ deletions in primary resected non-small cell lung cancer. Cancer Res 1993; 53: 1-4.

35. Quinlan D, Davidson A, Summers C, Warden H. Doshi H. Accumulation of p53 protein correlates with a poor prognosis in human lung cancer. Cancer Res 1992; 52: 4828-4831.

36. Chiba I, Takahashi T, Nau M, et al. Mutations in the p53 gene are frequent in primary, resected non-small cell lung cancer. Oncogene 1990; 5: 1603-1610.

37. Ebina M, Steinberg S, Mulshine J, Linnoila I. Relationship of p53 overexpression and upregulation of proliferating cell nuclear antigen with the clinical course of non-small cell lung cancer. Cancer Res 1994; 54: 2496-2503.

38. McLaren R, Kuzu I, Dunnill M, Harris A, Lane D, Gatter $\mathrm{K}$. The relationship of p53 immunostaining to survival in carcinoma of the lung. Br J Cancer 1992; 66: 735-738.

39. Hibi K, Takahashi T, Yamakawa K, et al. Three distinct regions involved in $3 p$ deletion in human lung cancer. Oncogene 1992; 7: 445-449.

40. Yokoyama S, Yamakawa K, Tsuchiya E, Murata M, Sakiyama S, Nakamura Y. Deletion mapping on the short arm of chromosome 3 in squamous cell carcinoma and adenocarcinoma of the lung. Cancer Res 1992; 52: 873-877.

41. Folkman J, Watson K, Ingber D, Hanahan D. Induction of angiogenesis during the transition from hyperplasia to neoplasia. Nature 1989; 339: 58-61.

42. Siravastava A, Laidler P, Davies R, Horgan K, Hughes L. The prognostic significance of tumor vascularity in the intermediate-thickness $(0.76-4.0 \mathrm{~mm}$ thick) skin melanoma: a quantitative histologic study. Am J Pathol 1988; 133: 419-423.

43. Folkman J, Haudenschild C. Angiogenesis in vitro. Nature 1980; 288: 551-556.

44. Nagy J, Brown L, Senger D, et al. Pathogenesis of tumor stroma generation: a critical role for leaky blood vessels and fibrin deposition. Biochem Biophys Acta 1989; 948: 305-326.

45. Liotta L, Kleinerman J, Saidel G. Quantitative relationships of intravascular tumor cells, tumor vessels, and pulmonary metastasis following tumor implantation. Cancer Res 1974; 34: 997-1004.

46. Macchiarini P, Fontanini G, Hardin M, Squartini F, Angeletti C. Relation of neovascularisation to metastasis of non-small-cell lung cancer. Lancet 1992; 340: 145-146.

47. Macchiarini P, Fontanini G, Dulmet E, et al. Angiogenesis: an indicator of metastasis in non-small cell lung cancer invading the thoracic inlet. Ann Thorac Surg 1994; 57: 1534-1539.

48. Roberts T, Hasleton P, Musgrove C, Swindell R, Lawson $\mathrm{R}$. Vascular invasion in non-small cell lung carcinoma. J Clin Pathol 1992; 45: 591-593.

49. Macchiarini P, Fontanini G, Hardin J, Pingitore R, Angeletti C. Most peripheral, node-negative, non-small cell lung cancers have low proliferative rates and no intratumoral and peritumoral blood and lymphatic vessel invasion: rationale for treatment with wedge resection alone. $J$ Thorac Cardiovasc Surg 1992; 104: 892-899.

50. Alberts B, Bray D, Lewis J, Raff M, Roberts K, Watson $\mathrm{J}$. The nucleolus is a ribosome-producing machine. In: Molecular Biology of the cell. New York, Garland Publishing Inc., 1989; p. 541.

51. Goodpasture C, Bloom S. Visualization of nucleolar organizer regions in mammalian chromosomes using silver staining. Chromosome 1975; 53: 37-50.

52. Kaneko S, Ishida T, Kenji S, Yokoyama H, Sugimachi K. Nucleolar organizer regions as a prognostic indicator for stage I non-small cell lung cancer. Cancer Res 1991; 51: 4008-4011.

53. Ishida T, Kaneko S, Akazawa K. Proliferating cell nuclear antigen expression and argyrophilic nucleolar organizer regions as factors influencing prognosis of surgically treated lung cancer patients. Cancer Res 1993; 53: 5000-5003.

54. Zimmerman P, Hawson G, Bint M, et al. Ploidy as a prognostic determinant in surgically treated lung cancer. Lancet 1987; 2: 530-533.

55. Asamura H, Nakajima T, Mukai K, Shimosato Y. Nuclear DNA content by cytofluorometry of stage I adenocarcinoma of the lung in relation to postoperative recurrence. Chest 1989; 96: 312-318. 
56. Filderman A, Silvestri G, Gatsonis C, Luthringer D, Honig J, Flynn S. Prognostic significance of tumor proliferative fraction and DNA content in stage I non-small cell lung cancer. Am Rev Respir Dis 1992; 146: 707-710.

57. Cibas E, Melamed M, Zaman M, Kimmel M. The effect of tumor size and tumor cell DNA content on the survival of patients with stage I adenocarcinoma of the lung. Cancer 1989; 63: 1552-1556.

58. Van Bodegom P, Baak J, Stroet-Van Galen C, et al. The percentage of aneuploid cells is significantly correlated with survival in accurately staged patients with stage I resected squamous cell lung cancer and long-term follow-up. Cancer 1989; 63: 143-147.

59. Ten Velde G, Schutte B, Vermeulen A, Volovics A, Reynders M, Blijham G. Flow cytometric analysis of DNA ploidy level in paraffin-embedded tissue of nonsmall cell lung cancer. Eur J Cancer Clin Oncol 1988; 24: 455-460.

60. Isobe H, Miyamoto K, Shimizu T, et al. Prognostic and therapeutic significance of the flow cytometric nuclear DNA content in non-small cell lung cancer. Cancer 1990; 65: 1391-1395.

61. Sahin A, Ro J, El-Naggar A, et al. Flow cytometric analysis of the DNA content of non-small cell lung cancer. Cancer 1990; 65: 530-537.

62. Pence J, Kerns B, Dodge R, Iglehart D. Prognostic significance of the proliferation index in surgically resected non-small cell lung cancer. Arch Surg 1993; 128: 1382-1390.

63. Alama A, Constantini M, Repetto L, et al. Thymidine labelling index as prognostic factor in resected nonsmall cell lung cancer. Eur J Cancer 1990; 26: 622625.

64. Tateishi M, Ishida T, Mitsudomi T, Sugimachi K. DNA polymerase $\alpha$ as a putative early relapse marker in nonsmall cell lung cancer: an immunohistochemical study. Cancer 1991; 68: 925-929.

65. Fontanini G, Macchiarini P, Pepe S. The expression of proliferating cell nuclear antigen in paraffin sections of peripheral, node-negative non-small cell lung cancer. Cancer 1992; 70: 1520-1527.

66. Ishida T, Kaneko S, Akazawa K, Tateishi M, Sugio K, Sugimachi K. Proliferating cell nuclear antigen expression and argyrophilic nuclear organizer regions as factors influencing prognosis of surgically treated lung cancer patients. Cancer Res 1993; 53: 5000-5003.

67. Merkel D, Dressler L, McGuire W. Flow cytometry, cellular DNA content, and prognosis in human malignancy. J Clin Pathol 1987; 5: 1690-1703.

68. Friedlander M, Hedley D, Taylor I. Clinical and biological significance of aneuploidy in human tumours. $J$ Clin Pathol 1984; 37: 961-974.

69. Gerdes J, Lemke H, Baisch H, Wacker HH, Schwab $\mathrm{M}$, Stein H. Cell cycle analysis of a cell proliferationassociated human nuclear antigen detected by monoclonal antibody Ki-67. J Immunol 1984; 173: 1710-1715.

70. Simony J, Pujol J, Radal M, Ursule E, Michel F, Pujol $H$. In situ evaluation of growth fraction determined by monoclonal antibody Ki-67 and ploidy in surgically re-sected non-small cell lung cancers. Cancer Res 1990; 50: 4382-4387.

71. Nakamura H, Morita T, Masaki S, et al. Intracellular localization and metabolism of DNA polymerase $\alpha$ in human cells visualized with monoclonal antibody. Exp Cell Res 1984; 151: 123-133.

72. Laskey R, Fairman M, Blow J. S phase of the cell cycle. Science 1989; 246: 609-614.

73. Baak J, Kurver P, De Snoo-Nieuwlaat A, De Graef S, Makkink B, Boon M. Prognostic indicators in breast cancer: morphometric methods. Histopathology 1982; 6: 327-339.

74. Paulson D, Stone A, Walther P, Tucker J, Cox E. Radical prostatectomy: anatomical predictors of success of failure. J Urol 1986; 136: 1041-1043.

75. Tosi P, Luzi P, Baak J, et al. Nuclear morphometry as an important prognostic factor in stage I renal cell carcinoma. Cancer 1986; 58: 2512-2518.

76. Tan G, Baak J. Evaluation of prognostic characteristics of stage I cutaneous malignant melanoma. Anal Quant Cytol 1982; 3: 1-5.

77. Ooms E, Essed E, Veldhuizen R, Alons C, Kurver P, Boon M. The prognostic significance of morphometry in T1 bladder tumours. Histopathology 1981; 5: 311-318.

78. Takise A, Kodama T, Shimosato Y, Watanabe S, Suemasu K. Histopathologic prognostic factors in adenocarcinomas of the peripheral lung less than $2 \mathrm{~cm}$ in diameter. Cancer 1988; 61: 2083-2088.

79. Cagle P, Langston C, Fraire A, Roggli V, Greenberg S. Absence of correlation between nuclear morphometry and survival in stage I non-small cell lung carcinoma. Cancer 1992; 69: 2454-2479.

80. Moolenaar C, Muller E, Schol D, et al. Expression of an N-CAM related sialoglycoprotein in small cell lung cancer and neuroblastoma. Cancer Res 1990; 50: 11021106.

81. Mooi W, Wagenaar S, Schol D, Hilgers J. Monoclonal antibody $123 \mathrm{C} 3$ in lung tumour classification: immunohistology of 358 resected lung tumours. Mol Cell Probes 1988; 2: 31-37.

82. Kibbelaar R, Moolenaar K, Michalides R, et al. Neural cell adhesion molecule expression, neuroendocrine differentiation and prognosis in lung carcinoma. Eur $J$ Cancer 1991; 27: 431-435.

83. Pujol J-L, Simony J, Demoly P. Neural cell adhesion molecule and prognosis of surgically resected lung cancer. Am Rev Respir Dis 1993; 148: 1071-1075.

84. Eisenstein B. The polymerase chain reaction: a new method of using molecular genetics for medical diagnosis. N Engl J Med 1990; 322: 178-183.

85. Stacey D, Degudicibus S, Smith M. Cellular ras activity and tumor cell proliferation. Exp Cell Res 1987; 171: 232-242.

86. James G, Goldstein J, Brown M, et al. Benzodiazepine peptidomimetics: potent inhibitors of ras farnesylation in animal cells. Science 1993; 260(1): 937-942.

87. Kohl N, Mosser S, Desolms S, et al. Selective inhibition of ras-dependent transformation by a farnesyltransferase inhibitor. Science 1993; 260: 1934-1937.

88. Fenton R, Taub D, Kwak L, Smith M, Longo D. Cytotoxic $\mathrm{T}$-cell response and in vivo protection against tumor cells harboring activated ras proto-oncogenes. $J$ Natl Cancer Inst 1993; 85: 1294-1302.

89. Graziano S, Mazid R, Newman N, et al. The use of neuroendocrine immunoperoxidase markers to predict chemotherapy response in patients with non-small cell lung carcinoma. J Clin Oncol 1989; 7: 1398-1406. 